\title{
The Socio-Political Effects on Using Puns in Iraqi Arabic Jokes
}

\author{
Marwah Kareem Ali \\ Department of Translation, College of Arts, Tikrit University, Salahaddin, Iraq
}

\begin{abstract}
Jokes can be effective and can achieve various purposes depending on how they are said or written. It is a fact that jokes refer to statements with humorous effect used as a means of entertainment to make people laugh and feel happy. However, jokes can have other socio-political meanings depending on the expressions found in them. This can be achieved through the employment of expressions denoting pun. Additionally, meanings of pun can be expressed in different ways depending on the socio-cultural characteristics of the community. Therefore, this study aimed at defining the socio-political impact of employing pun expressions in Iraqi jokes based on the socio-cultural specificity of the Iraqi community. To conducted such a study, this required using a qualitative method with a critical analysis. The data of this study were represented by (15) jokes written in Iraqi Arabic dialect (Iraqi colloquial language) and translated into English to be understood by those who do not speak Arabic language. Pun expressions were italicized in both source and target texts to be distinguished from other expressions in the joke. The results of this study revealed the influence of socio-political situations on creating jokes in Iraqi society. Moreover, the most notable type of pun used in Iraqi jokes was homonymous. This is due to that Iraqis intentionally tend to conceal the real intended meaning by using words that have the same spelling and pronunciation but carry different connotations.
\end{abstract}

Index Terms - Homonym, Iraqi Jokes, Iraqi Colloquial Language, Pun, Socio-Political Effects.

\section{INTRODUCTION}

The humorous power of jokes and humor is found through vagueness that is obvious in the English language. This vagueness is related to a linguistic term known as pun which is defined as the use of word play method to show/hide certain meanings through effective use of language. Hence, some jokes depend on sounds resemblances (e.g., sprain (illness) vs. Spain (country)), others rely on ambiguity in the meaning of words (such as trunk (of a car) vs. trunk (of an elephant)). On the other hand, other jokes may depend on linguistic representations that are similar in terms of syntax (like rose (the flower) vs. rose (past tense of rise)). Within linguistics field, there also appears "a corpus of jokes that distinguishes itself not by actions or situations but based on certain linguistic attributes or features of natural language for their effect" (Zabalbeascoa, 1996, p.
253). Such type of jokes is known as pun. Pun-based jokes can be categorized as either verbal or referential based on the qualities exhibited by them (Seewoester, 2009). The focus of existing literature on pun, jokes and humor is mainly on the way of processing pun expressions for funny interpretation as well as in relation to issues faced in translation (Seewoester, 2009). As Bucaria (2004) notes:

...structural ambiguity in English is also favored by the morphologic characteristics of the language, where a noun often has the same form of a verb, or vice versa, or the past tense and the past participle of a verb often coincide" and "[word class ambiguity] is quite common in English, unlike in other languages, given the capacity of the same word to function as a noun, a verb or something else depending on the context (p. 13).

The manifestation of puns, jokes and humor can be achieved in various ways ranging from clowning comedy to situationbased humor. Accordingly, some jokes exploit funny actions (e.g., "The Three Stooges"); whereas other jokes utilize "a comedy of errors" (such as "Much Ado About Nothing"). Sometimes a speaker says something that is not true for the purpose of joking, being ironic, being sarcastic, or emphasizing a point by way of exaggeration. These types of false statements concern the speaker's beliefs about the listener's knowledge (i.e., second-order belief attribution). Hence, the speaker assumes that the listener knows the truth (Taylor, Lussier, \& Maring, 2003).

This paper therefore attempts to highlight the socio-political effects on sing puns in Iraqi jokes. Many people think that humors and jokes are used for entertainment purposes only. But this idea is not always true because they can be used to denote hidden meanings behind expressions used within them. This can be achieved through using puns. Thus, the main questions in relation to such issue are: What is meant by jokes and puns? What are the main purposes of using puns in Iraqi jokes? This study is important because it is related to the sensitive aspect of jokes in relation to employing pun expressions to denote hidden meanings. Such expressions are defined in this study in order for readers to be able to understand the intended meanings behind using puns in Iraqi jokes, in particular those related to Iraqi colloquial language.

Journal of University of Human Development

Volume 5 No. 3(2019); DOI: 10.21928/juhd.v5n3y2019.pp176-181

Regular research paper: Published 5 August 2019

Corresponding author's e-mail: marwakareem16@tu.edu.iq

Copyright (02019 Marwah Kareem Ali. This is an open access article distributed under the Creative Commons Attribution License

(CC BY-NC-ND 4.0) 


\section{LITERATURE REVIEW}

\section{A. Definition of Humor and Pun in English and Arabic}

Humor involves many different types, like irony, pun, sarcasm, and double entendre...etc., in which each type generates humor by its own way and create hilarious situations (Dhiaa \& Abbas, 2016). Recently, UN umbrella is a term used to refer to the word 'humor', with generally positive social desirable connotation, and it includes anything people do or say that is perceived, heard, and understood as funny and laughable. The word 'humor' is said to have a very complex history and it had a totally different meaning from the meaning that we know in the present time (Martin, 2007).

Pun is a method of word play usually defined as a "deliberate communicative strategy, or the result thereof, used with a specific semantic or pragmatic effect in mind" (Delabatista, 1997, p. 2). Furthermore, word play itself is used as a general name for numerous strategies employed in texts. Based on such strategies, authors utilize the language structure to create two similar expressions with different/similar meanings. Pun is performed in uttering/writing a phrase/sentence using two words that have the same pronunciation (homophones or homonyms) but with different meanings (polysemy) (Bader, 2014).

Similarly, The Free Wikipedia Encyclopedia defines pun as "a form of word play which suggests two or more meanings of words or of similar-sounding words, for an intended humorous or rhetorical effect". Merriam-Webster Dictionary puts it simply as "the humorous use of a word in a way that suggests two interpretations." Partington (2009, p. 1794) defines pun phonetically as "the dissociative play between two sound sequences." In addition, "the relationship between the different meanings of the two word sequences... will affect its quality, its success or failure." (Partington, 2009, p. 1794).

Leech (1969, p. 209) highlights that the nature of expressions used to refer to word play or pun is polysemous (one word having different but related senses) and homonymous (different words having identical forms). For example, the word bank carries the homonymous nature implied in such structures like "the bank of the river and the bank for money storing". The polysemic feature can be shown in the word foot, as in "the foot of the man, the foot of the mountain and the foot-long snake".

Pun can be used in different forms or texts, but it is most common found in TV comedy shows, cinema and literary texts. Additionally, it is widely used in many newspaper articles nowadays. Such journalistic articles are so-called ironic or sarcastic columns. These columns tackle daily socio-political problems and issues related to society and governments using a humorous style. The purpose behind such ironic columns is to attract readers and raise their fully awareness of these problems (Bader, 2014). In fact, pun, satire and irony are regarded as different forms of humor that is commonly used in newspapers and magazines. The humor of pun and other verbal jokes derives from the fact that humans express their ideas and feelings through circumscribed and logical elements. Any deviation from these elements is felt as a release from conventional restrictions and is, therefore, humorous. "Punning can also be viewed as a test of one's power over other participants in the communicative act." (Delabatista, 1996, p. 140).
In Arab world, authors support pun definitions mentioned above. The arabic term that represents pun expression is known as (التورية) at-tawriyah. Arab authors like Al-Hamawi state that at-tawriyah is realized in the text through the use of one word with two different meanings. Hence, one of these meaning is metaphorical; while the other one is denotational. The denotational meaning is the unintended (or called close) meaning; whereas the metaphorical meaning is the intended (or can be called remote) one. In other words, the writer or speaker intends the remote meaning. In the same vein, Al-Muraghi emphasizes on exploring what is called the "near" and "far" meanings of one single word used for pun (Bader, 2014, p. 19).

\section{B. Types of Humor}

Many different types of humor are introduced. Each one of them creates humor in its own way. They are as follows:

\section{1) Wit}

Wit is described as a style of humor; and the witty person has "the talent or quality of using unexpected associations between contrasting or disparate words or ideas to make a clever humorous effect" (Arbuckle, 2008, p. 13).

\section{2) Sarcasm}

Herawan, Deriss and Albawajy (2013, p. 281) define sarcasm as "the use of irony to mock or convey contempt" and "it is the activity of saying or writing the opposite of what you mean, or of speaking in a way intended to make someone else feel stupid".

\section{3) Irony}

Irony is considered the most common way to create humor. Quintilian said that "irony, is that figure of speech or trope in which something, which is contrary to what is said, is to be understood".

\section{4) Pun}

Pun is also considered one of the ways to create humor. It was defined by the Shorter Oxford Dictionary as "the use of the word in such a way as to suggest two or more meanings, or the use of two or more words of the same sound with different meanings, so as to produce a humorous effect; a play on words".

\section{Types of Pun in English}

Puns are classified into different forms. They include the following (Bader, 2014, pp. 10-20):

\section{1) "Homophonic Pun"}

Pun related to this kind refers to using pairs of word, which are homophones (have the same sound or pronunciation with different spelling); however, these word pairs are not synonyms because they denote different meanings. For instance, "Atheism is a non-prophet institution". The word "prophet" in this example is used instead of "profit", which is "the usual word used in expressions like non-profit organizations".

\section{2) "Homographic or Heteronymic Pun"}

In this type, pun is related to words that have the same spelling with different pronunciation and meanings, as in "You can tune a guitar, but you can't tuna fish unless of course you play bass." This sentence contains two types of pun: the first 
type is homophonic that is clearly shown by "tune" and "tuna". The second one is homographic represented by the word "bass". This word "bass" has a kind of ambiguity due to the identical spelling. The word "bass" can mean "a string instrument" and can refer to "a kind of fish".

\section{3) “Homonymic Pun”}

This kind consists of exploitation of words, which are both homophones and homographs. For example: "Did you hear about the little moron who strained himself while running into the screen door?" The word "strained" denotes two meanings: "gave much effort" and "filtered".

\section{4) Compound Pun}

This type refers to a statement containing two or more expressions of pun. For instance: "Why can't a man starve in the Great Desert? Because he can eat the sand which is there, but what brought sandwiches there? Noah sent Ham and his descendants mustered and bred." This statement has two puns: the phrase "sand which", which is homophonic with "sandwiches"; and the homonymic words "Ham (Noah's son)" and "ham (kind of pig meat)", "mustered/mustard", and "bred/bread".

\section{5) Recursive Pun}

Based on this type, interpretation of pun that is found in the second aspect depends on the understanding of an element in the first aspect, as in "Infinity is not in finity" which means that infinity is not in the finite range.

\section{6) Visual Pun}

This type of pun is more related to the use of pictures and images. Thus, it is sometimes used in comics and cartoons, such as "The Far side". Naming or proper names wordplay (Kaufmann) fulfills an important role in the literary and semiliterary works and scriptures, ranging from "Asterix comic strips to Dante and Dickens (e.g. Oliver Twist)".

\section{7) Idiom-Based Pun}

In this type, idioms used in pun expressions are manipulated for the purpose of obtaining a playful humorous effect. It is, therefore, requires a conflict between "the compositional, literal reading of the idiom and its accepted figurative meaning, such as the idiom 'to be in the doghouse" (Delabatista, 1994, p. 15).

\section{Types of Pun in Arabic}

Puns in Arabic can be classified into the following categories (Khanfar, 2013, pp. 30-32):

1. (تام): In this kind of pun, the words are exactly of the same forms and spellings, but of different meanings; e.g., (ساعة: Judgment Day and time). Being of the same characteristics, homonym is this pun's counterpart in English.

2. (ناقص): This term is used when the two similar words are different in the number of letters, i.e. extra letters are added to one of the two words. These extra letters can be in the beginning, middle, or at the end like (البحر /البر). The addition of the extra letters to the beginning of one of the two words makes another kind of pun called (مطرّف) like
(مساق and). On the other hand, if this addition occurs at the end of one of the two words, it would be called (مذيّل) like (مدار and مدارج).

3. (مضارع): The term is used when the similar words are different just in one letter in each word. This kind of pun occurs when the place of the articulation of the two different letters is almost the same, like (خير and خيل). On the basis of similarity and closeness of sounds, paronomy can be equated with this kind of pun.

4. (لاحق): In this kind of pun, the similar words are differentiated both by a single letter (in each word) and

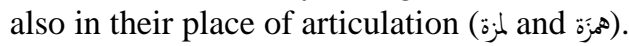

5. (مرّف): In this kind of pun, the difference of the similar words arises from the difference in the diacritics of the two

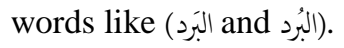

6. (مصحّف): The two similar words are differentiated by dots above or below the letters (يحسنون and يحسبون).

7. (قلب): In this kind of pun the reversion of the letters happens either in the whole or one part of structure of one of the two words (فكيه Sفيه and Anagrams in English are very much close to this kind of Arabic pun.

8. (مستوى): This kind of pun is found in phrases or sentences which are read the same, backwards or forwards; to this extent, they are read from the end to the beginning as if they are being read from the beginning to the end like (كل في الفلك). Palindrome, a type of English pun, is regarded as equivalent to this Arabic pun. 'Live not on evil' provides a relevant example.

9. (اشتقاق): In this kind of pun, the two different words are puns that derive from the same root like (سلم) and ang (ملمن). Polyptoton one type of homophonic puns, is the English equivalent of this pun.

10. (شبه اشتقاق): In this kind of pun, similar words are derived from different roots (e.g. قال and قالين).

\section{E. Humor in Pun}

According to Delabatista (1996, p. 138), the humor of a pun depends very much on the "expectations shared by the framer of the message and the addressee and on the way the latter is taken by surprise and plunged into something entirely different from what $\mathrm{s} /$ he has been prepared for". Wordplay or pun is generally based on a "confrontation or clash of two meanings". Moreover, pun expressions "result not only from the confrontation of two (or more) different meanings of an identical or similar string of letters or sounds, but also from the clash between two (or more) domains of human knowledge and experience." Delabatista (1996) adds that the use of punning

...is possible in any language in so far as it seems to be universal feature of language to have words with more than one meaning (polysemy), different words with the same spelling or pronunciation (homographs and homophones) and words which are synonyms or near synonyms while having different pragmatic meanings and evoking different associations. Punning should also be considered in relation 
to another important aspect of human nature, namely our own sense of humor and our desire to produce a humorous effect on the people we communicate with. The wordplay comic effect strength is determined by showing the distance between the domains of human knowledge and experiences and the way they are connected. Wordplay is inherently linked with the asymmetrical relationship between language and the extra linguistic world, which... is geared to the optimum use of our information processing system (pp. 138-139).

In this sense, punning is "a perfect illustration of the close ties between language and thought." Also, punning depends on "the asymmetry between the more or less limited number of language signs and the much greater number of entities, events, and relationships experienced by us and we try to describe by means of language." (Delabatista, 1996, p. 152).

\section{METHOD}

This study was based on the qualitative research method with a critical analysis. The data of this study were represented by (15) jokes written in Iraqi Arabic dialect (Iraqi colloquial language). These jokes were translated into English to be understood by those who do not speak Arabic language. Pun expressions were italicized in both source and target texts to be distinguished from other expressions in the joke. In particular, this paper focused on studying the use of homonym as the main type of pun; whereas other types were not considered.

\section{RESULTS AND DISCUSSION}

It is obvious that the jokes under study have various connotations that correspond to the Iraqi socio-cultural specificity. In Iraq, people, especially youth, employ homonyms to create jokes with ironic effect. In addition to being a means of entertainment, Iraqi jokes implied sociopolitical characteristics reflecting the reality of the Iraqi community. This section presents the analysis of pun expressions in a number of Iraqi jokes. These jokes are analyzed in terms of their intended meaning behind the use of pun expressions; adding to the socio-political effects of such expressions on the creation of jokes. Each joke is translated into English and then analyzed to highlight the effective use of pun expressions in relation to the intended meaning.

1. محشش يحقق وياه ظابط وسأله وين ساكن ؟ ؟؟ كله ويه اخويه .... كله وين ساكن

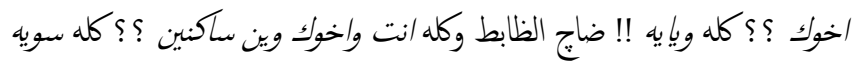

سيدي.

- (A detective inquiring a stoned man and asked him: where are you living? He said: with my brother. The detective said: where is your brother living? He said: with me!! The detective became angry and said: where are you and your brother living? He said: together, my sir).

This joke has pun expressions, which are italicized to be distinguished. It reflects the way in which detectives inquire the accused. So, the detective asks the accused about the place where he lives, but the accused thinks that the detective asks him that with whom he is living. In fact, this joke can imply two meanings. Firstly, it may indicate misunderstanding of detective's question. Secondly, it may indicate that the accused disrespects the detective. Thus, he does not answer to detective's question directly.

2. طفل كال لمعلمته: تدرين ست شكد أني أحبج...وبلكي أتزوجج؟ فالمعلمه كالت :

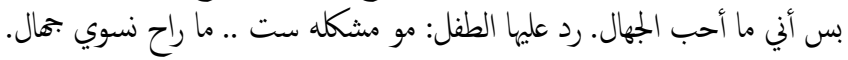

- (A child said to his teacher: teacher, you know how much I love you and I want to marry you? The teacher said: but I don't love children. He replied: no problem teacher; we will not have children).

Some children are daring, especially in school when they meet a beautiful teacher. So, they can say anything without shame. This joke represents this social fact. This expression (أني ما أحب (الجهال), which is said by the teacher, is misunderstood by the child who thinks that the teacher doesn't want to have children after marriage, so he said it is okay (ما راح نسوي بجال').

$$
\text { 3. لمششة ضايجة ، جارتهاكالت هاي ليش ضايجة ، المحشة كالت دزيت ابو الجهال }
$$

- (A stoned girl is annoyed, her neighbor asked her why you are annoyed? The stoned girl said I sent my husband to market to buy bean, then a car has hit him and died. Her neighbor asked her what will you do? She said I will cook okra).

This joke reflects that this woman is more concerned about what to cook, not about what happened to her husband. This is shown in these expressions (و شر اح تسوين) and (اسوي باميا). Her neighbor wonders about what she will do without her husband, but she thinks that her neighbor asks her about what she will cook.

$$
\text { 4. "وحدة كَالت لامحا دا اتصل بزوجي ومدا يرد اخاف يطلع متزوج ردت الام :ماما }
$$

- (A woman told her mother that I am calling my husband but he doesn't answer, I am afraid he has married. Her mother said: my daughter, be optimistic; maybe there has been an explosion and he died).

In this joke, it is clear that there is a contradiction between (تفيوز صار انفجار ومات) in the first one, the woman expects that her mother will say something good about her husband, but the mother something very bad that is explosion and death of her daughter's husband.

$$
\text { 5. واحد سأل محشش قال له هذا البنك فاتح قاله المحشش لا غامق. }
$$

- (A man asked a stoned man that is this Bank open? The stoned man said no, it is dark).

In this joke, a man is asking whether the bank is open or close, but the stoned man said (غامق) thinking that he is asking about its color whether it is light or dark. 


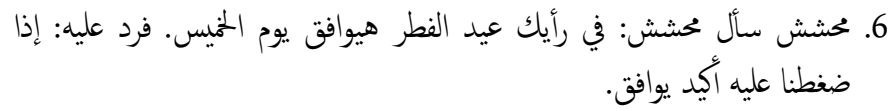

- (A stoned man asked another stoned man: do you think that Eid al-Fitr will be on Thursday? He replied: If we enforce it, for sure it will agree).

In this joke, the stoned man is asking about the day of Eid alFitr would it be on Thursday or another day, but the other man answered using this expression (إذا ضغطنا عليه أكيد يوافق) referring to another matter which is about its agreement or disagreement to be on Thursday.

$$
\begin{aligned}
& \text { 7. "واحد لوتي سأوه: امك حيه؟؟ كال لا عكربه كالوله: لأ.. يعني هيه عايشه؟؟ } \\
& \text { كال: لا خديجه كالوله: قصدنا عدله ؟؟ كال: لعد قابل عوجه. }
\end{aligned}
$$

- (A loiterer man was asked: is your mother alive? He said: no, she is scorpion. They said: no, we mean is she among the living? He said: no, she is Khadijah. Then, they said that we mean is she existing? He replied: sure, she is. Do you think she is crooked?)

The expressions used in this joke denote two meanings that (حية) could refer to the name of an animal (snake) or being alive, (عايشه) could mean a name of a woman (Ayshah) or also being alive, and (عله (ع) could mean a beauty description (fairness) or being alive. This is demonstrated by his expressions (عكربه) thinking that they ask about which animal resembles his mother, (خديجه) thinking that they are asking about her name and thinking that they are asking how she is looking, that he used to reply to each question, respectively.

$$
\begin{aligned}
& \text { 8. عراقي جاي يناقش رسالة دكتوراه بلندن بعد ما انتهت المناقشة مالته الدكتور كاله } \\
& \text { انا لم اقتنع برسالتك جاوبه العراقي انت برسالة محمد ما مفتنع وهي نازلة من السهاء } \\
& \text { تريد تقتنع برسالتي واني جاي من العراق. }
\end{aligned}
$$

- (An Iraqi student was discussing his doctoral dissertation in London. After his discussion has ended, the professor said: I'm not convinced of your dissertation. Then, the Iraqi replied: you are not convinced of Mohammed's message which is sent down from heaven, so how do you want to be convinced of my dissertation and I am coming from Iraq?)

The word (رسالة) could refer to a prophetic message, an ordinary message or an academic thesis. In this joke, the student used this word to refer to the Islam message not his doctoral dissertation.

9. اكو واحد انخطفت عمته (ام زوجته) اتصلو بيه العصابة كلوله لوتنطينا 5 شدات لو نحركها بالبانزين فراح لزوجته كلها هيجي وهيجي السالفة والعصابة انطوني محلة

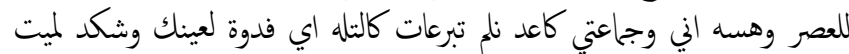

$$
\text { ليهسه كلالها والله لبهسه صار جامع تقريبا } 3 \text { براميل بانزين. }
$$

(There is a man whose mother in law has been kidnapped. The kidnappers phoned him and told him that either you have to pay $5000 \$$ or we will burn her with gasoline. He told his wife about this matter and that the kidnappers gave him a chance till afternoon; and now I and my friends are collecting donations. She said many thanks to you. How much have you_collected till now? He said I swear we have collected nearly 3 barrels of gasoline).

This joke shows the social reality of the bad relationship between mother in law and her son-in-law in Iraqi community. It is a fact that most mothers in law hate their sons-in-law and vice versa, and that each one of them wishes to get rid of them by any means. In this joke, the woman thought that her husband wants to save and protect her mother from kidnappers when he said (كاعد نلم تبرعات) so that she said (وشكد لميت ليهمة). But the reality is that he wants to get rid of his mother in law so he said ( تقريبا 3 (براميل بانزين

$$
\text { 10. بصراحة انا ادور علاقة جديدة لان العلاقة الي اعلق فيها ملابس انكسرت. }
$$

- (Frankly speaking, I'm looking for a new clothes hanger because my clothes hanger has been broken).

In Arabic, the word (علاقة) could refer to different meaning in English, e.g., relationship, bag, or hanger. At first, one may think that the first expression (علاقة جديدة) may refer to a new relationship, but when completing the sentence, s/he will understand that it refers to (a new hanger) not (a new relationship).

$$
\begin{aligned}
& \text { 11. واحد حشاش اتصل على رقز جاوب عليه واحد هم حشاش كاله العفو بيت ابو }
\end{aligned}
$$

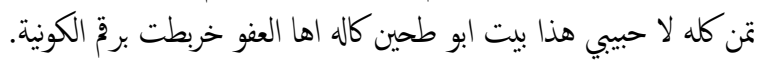

- (A stoned man phoned an unknown number and a stoned man also replied him. He said: excuse me, is this number of abo Tman (rice)? The other one replied: no, my love; it is of abo Tahin (flour). So, the first said: ah, sorry I have been mistaken by the number of bag).

In Iraq, it is acceptable to name sons and daughters with names of objects, plants, animals, countries names, or any odd names. So, it is not surprising to hear such expressions as (ابو تن ) and (ابو طحين). But in this joke the men are using these names as a matter of joking not of naming.

$$
\text { 12. مدرس علوم يشرح لمحششين يقول يعيش السمك في الماء ردوا المحششين يعيش يعش }
$$

- (A science teacher explains for stoned students saying that: fish is living in water. The stoned students chanted: long live, long live, long live).

In fact, the word (يعش) can be used to refer to life or to a hope for having a long life, especially when being said and repeated more than one time by people to the rulers. So, the students repeated the word (يعيش) three times thinking that the teacher intends (a hope for having a long life).

$$
\text { 13. قال الزوج لزوجته تزا مليت من عشرتح قالت الزوجة اذا مليت من عشرتي }
$$


- (The husband said to his wife: I am tired of your companionship. The wife said: if you are tired of my companionship, so exchange it in to two fives).

Also, the word (عشرة) could refer to the number (10), a relationship or companionship. So, the woman used the expression (صرفه خمستين) referring to a number not a relationship.

$$
\text { 14. اتصل عليها بعد فراق طويل قال ما حنيتي ؟ قالت لا بس صبغت شعري. }
$$

- (He phoned her after long parting and said: did you miss $m e$ ? She said: no, I have only dyed my hair).

Here, the word (حنين) could refer to nostalgia, yearning or it could refer to (حبغت (حنة) referring to herbal dye. So, she said (نشعري thinking that he asked her whether she changed her hair color or not.

15. تسألها من وين هالجمال؟ بتقول من الله وهي مسوية عمليات اكثر من حزب

- (a woman, when asked about her beauty, said: it is natural beauty, but, in fact, she has undergone surgeries more than Hezbollah).

In this joke, the word (عمليات) refers to cosmetic surgeries, but it has another meaning implied in (اكثر من حزب الهُ) referring to the military operations of Hezbollah. This means that women tend to undergo cosmetic surgeries several times in order to be more beautiful. On the other hand, the joke compares the number of cosmetic surgeries to that of military operations of Hezbollah. This could also imply that the joke is created to underestimate the importance of military operations of Hezbollah compared to the importance of cosmetic surgeries in the Arabic world.

Table 1 below illustrates examples of homonyms used in the jokes analyzed in this study.

TABLE I

HOMONYMS AND THEIR MEANINGS

\begin{tabular}{|c|c|c|}
\hline Homonyms & Apparent meaning & Intended meaning \\
\hline فات & Light (color) & Open \\
\hline 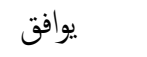 & Agree & Specify the date \\
\hline حيd & Snake & Alive \\
\hline عايشه & Aisha (name) & Among the living \\
\hline رسالة & Dissertation & Prophetic Message \\
\hline ت تبرعات & $\begin{array}{l}\text { Donations (for good } \\
\text { work) }\end{array}$ & $\begin{array}{c}\text { Donations (for } \\
\text { doing bad things) }\end{array}$ \\
\hline علاقة & Relationship & Clothes hanger \\
\hline يعيش & Live & Long live (as a slogan) \\
\hline عشرة & Ten (as a number) & Companionship \\
\hline حنيت & $\begin{array}{c}\text { Henna (Dye for hair } \\
\text { used in Asian and } \\
\text { African countries) }\end{array}$ & Yearning \\
\hline عمليات & Cosmetic surgeries & Military operations \\
\hline
\end{tabular}

As shown in table 1, the arabic words have more than one meaning. One of these meanings is apparent, which is not the intended meaning; while the other one is the intended meaning. When reading these jokes thoroughly, one would understand that they reflect the socio-cultural impact of society on the creation of jokes.

\section{CONCLUSION}

Iraqi people reflect the reality of their socio-political situation by using entertainment means, and joke is one of these means. When used effectively, jokes can achieve other purposes than their real one, which is entertainment. The humorous nature of jokes conceals the real purpose behind uttering them. This is illustrated through employing pun expressions, especially homonyms, which imply different meanings. Concerning the effective use of such expressions in relation to the sociopolitical aspect, some jokes imply irony and disrespect. It can be concluded that the power of words can be implied in different means regardless of their type or purpose. What makes words powerful is the way in which they are employed. This power can be explored more when analyzing facial expressions or body gestures along with uttering jokes that contain homonyms. Consequently, it is recommended to study the effect of body expressions on defining the intended meaning behind uttering jokes.

\section{REFERENCES}

Arbuckle, G. A. (2008). Laughing with God: Humor, Culture and Transformation. Minnesota: Liturgical.

Bader, Y. (2014). A Linguistic and Cultural Analysis of Pun Expressions in Journalistic Articles in Jordan. European Scientific Journal, 2(June), SPECIAL edition.

Bucaria, C. (2004). Lexical and syntactic ambiguity as a source of humor: the case of newspaper headlines. Humor, 17(3), 279-309.

Delabatista, D. (1994). Focus on the Pun: Wordplay as a Special Problem in Translation Studies. Amsterdam: Rod Opi.

Delabatista, D. (1996). Wordplay and Translation. Manchester: St. Jerome Publishing.

Delabatista, D. (1997). Traductio: Essays on Punning and Translation. Manchester: St. Jerome Publishing.

Dhiaa, S., \& Abbas, N. F. (2016). Pun and (Un)Intentional Humor. Journal of American Academic Research, (February).

Herawan, T., Deriss, M., \& Albawajy, J. (2013). Proceedings of. In the First International Conference on Advanced Data and Information Engineering. London: Springer.

Khanfar, A. K. (2013). The Translation of Puns a Semantic or Pragmatic Equivalent. An-Najah National University, Nablus, Palestine.

Leech, G. N. (1969). A linguistic Guide to English Poetry. New York: Longman.

Martin, R. A. (2007). The Psychology of Humor: An Integrative Approach. California: Academic press.

Partington, A. S. (2009). A Linguistic Account of Wordplay: The Lexical grammar of punning. Journal of Pragmatics, 41(9), 1794-1809.

Seewoester, S. (2009). Linguistic Ambiguity in Language-based Jokes. DePaul University.

Taylor, M., Lussier, G., \& Maring, B. (2003). The Distinction Between Lying and Pretending. Journal of Cognition and Development, 4(3), 299323.

Zabalbeascoa, P. (1996). Translating jokes for dubbed television situation comedies. The Translator, 2(2), 235-257. 